\title{
ESTABLISHMENT OF THE REGULARITIES OF THE CONCENTRATIONS CHANGE OF MICROORGANISMS AND WATER-SOLUBLE COMPOUNDS IN POLLUTED WATER AFTER ULTRASOUND TREATMENT
}

\author{
Volodymyr Starchevskyy $^{1}$, Nataliya Bernatska ${ }^{1,}{ }^{凶}$, Iryna Typilo ${ }^{1}$, Lilianna Oliynyk $^{1}$, \\ Orysia Strogan ${ }^{1}$
}

https://doi.org/10.23939/chcht15.03.408

\begin{abstract}
The regularities of the change of the concentration of microorganisms and water-soluble organic compounds in the polluted water in the conditions of cavitation treatment and the influence of the amount of biological water pollution on the value of the chemical oxygen consumption are investigated.
\end{abstract}

Keywords: ultrasound, Saccharomyces cerevisiae, destruction of microorganisms, yeast cells aggregate, reaction kinetics.

\section{Introduction}

In Ukraine, the food industry is one of the leading industries that are developing dynamically [1]. However, this industry is one of the sources of negative impact on the environment. According to the degree of intensity of the food industry interaction with the environment, the first place among the objects of nature is occupied by water resources $[1,2]$. Food industry enterprises are one of the largest water consumers, where $95 \%$ of wastewater generated during production contains high concentrations of pollutants [3, 4]. Water in food production is used in most technological processes of obtaining products as the main or auxiliary raw material [5]. Most of this water in the form of contaminated effluents is removed from the process and enters the environment [6]. A significant part of this wastewater is represented by highly polluted waters, characterized by the value of COD from 2000 to $60,000 \mathrm{mgO} / \mathrm{dm}^{3}$. The amount of pollution by the value of biological oxygen demand (BOD) ranges from 550 to $1200 \mathrm{mg} / \mathrm{dm}^{3}[7,8]$. Such wastewaters have $\mathrm{pH}$ of $4.3-$ 5.5 , contain suspended solids, the concentration of which

\footnotetext{
${ }^{1}$ Lviv Polytechnic National University

12 Bandera St., Lviv 79013, Ukraine

Nataliia.L.Bernatska@lpnu.ua

(C) Starchevskyy V., Bernatska N., Typilo I., Oliynyk L., Strogan O., 2021
}

is $380-910 \mathrm{mgO} / \mathrm{dm}^{3}$, they are characterized by a stable dark brown color, high concentration of organic and mineral compounds and do not meet the requirements of the standards for further treatment at sewage treatment plants[9].

A large amount of wastewater is formed at the stage of washing and soaking barley, washing yeast, washing production tanks, pipelines and containers [8]. Brewery wastewater contains solutions of sugars, proteins, inorganic salts, they also contain particles of earth and grain. The most polluted is wastewater, which is formed during washing and soaking of grain, from spent hops and washing of used yeast $[10,11]$.

The efficiency of ultrasonic treatment of wastewater, as an alternative method of wastewater treatment of food industry enterprises, largely depends on the presence of impurities, concentration and nature of various microorganisms [11]. Wastewater is a very complex object for research, because under the influence of cavitation it undergoes oxidation of organic compounds by microorganisms, decomposition of macromolecular compounds, protein coagulation, enzyme inactivation, autolysis of cells of microorganisms with the release of water-soluble organic compounds of different composition, development of pathogenic microorganisms on decay products of nonpathogenic microorganisms and other processes [12]. Under the influence of ultrasound treatment, significant mechanical destruction of both the cell wall and the cytoplasmic membrane and other structures, leaching of the cell contents into the environment were recorded $[13,14]$.

Due to the duration of BOD determination, the COD value is more often used in factory practice. If the wastewater contains organic substances resistant to biological oxidation, the determination of COD is the most reliable way to assess the content of organic pollution [14]. However, the content of microorganisms in wastewater may give an error in the determination of $\mathrm{COD}$, as the existing microorganisms in the water will also be oxidized by potassium dichromate. Therefore, it is 
important to study the dependence of the COD value on the microbial count of wastewater and changes of the concentration of microorganisms and water-soluble organic substances in contaminated water after sonication.

The aim of this work is to study the change in the concentration of yeast and rot microorganisms, as well as water-soluble organic substances in the dispersion of yeast treated with ultrasound.

\section{Experimental}

Dispersions of active dry yeast Saccharomyces cerevisiae of different concentrations were used for study. The dry yeast was dispersed in 1 liter of distilled water by stirring at room temperature. The dispersion contained 1$8 \%$ of dry yeast Saccharomyces cerevisiae. The resulting dispersion was diluted with water to obtain dispersions with concentrations of $0.1-0.8 \mathrm{~g} / \mathrm{dm}^{3}$. An ultrasonic generator UZDN-2T with an operating frequency of $22 \mathrm{kHz}$ and a power of $40 \mathrm{~V} \cdot \mathrm{min}^{-1}$ was used for the yeast dispersions treatment. Ultrasonic vibrations from the UZDN-2T generator were transmitted using a magnetostrictive emitter immersed in the volume of the test liquid $\left(100 \mathrm{~cm}^{3}\right)$ with a known value of chemical oxygen demand and microbial number.Ultrasonic treatment was performed at a temperature of $309 \mathrm{~K}$.

During the experimental studies, the optical density, $\mathrm{pH}$, and COD of the obtained dispersions were measured. The number of yeast cells was determined by surface seeding on wort agar. The most probable number (MPN) of vitable microorganisms was investigated in each sample. The MPN of rot microorganisms was determined by surface seeding on the meat-peptone agar medium before and after treatment [11]. The essence of the method of determining the total microbial number is to determine the number of microorganisms capable of growing on meat peptone agar at a temperature of $310 \pm 0.5 \mathrm{~K}$ for $24 \pm 2 \mathrm{~h}$ in $1 \mathrm{ml}$ of water, followed by calculation of the number of colonies grown on this medium.

The $\mathrm{pH}$ values of the samples were measured with an accuracy of \pm 0.5 using the $\mathrm{pH}$ meter $\mathrm{pH}-673$. The optical density of the dispersion was measured on FEKN$56 \mathrm{M}$ at wavelengths from 364 to $434 \mathrm{~nm}$. The COD values were measured by back-titration of samples [12]. The change in time of COD, the number of live yeast and the microbial number were investigated in the surface layer of water with a thickness of $5 \mathrm{~cm}$.

\section{Results and Discussion}

When determining the amount of chemical pollution of water, an indicator of chemical oxygen demand is used, which shows the amount of oxidant $\left(\mathrm{K}_{2} \mathrm{Cr}_{2} \mathrm{O}_{7}\right)$ spent on the oxidation of chemicals per unit volume of water solution or dispersion and has a dimension of $\mathrm{mg} / \mathrm{dm}^{3}$. This parameter is proportional to the content of organic substances capable of oxidation in solution and can be used to quantify changes in the concentration of organic substances. However, in the presence of microorganisms in water under the conditions of COD analysis, all their organic component will be also oxidized and in the analysis of water with simultaneous content of organic and biological pollution it is unknown what contribution to total water pollution is made by microorganisms and which by organic substances. Therefore, we conducted experiments to determine the COD value in model mixtures containing only yeast cells.

As a model system, we chose the dispersion of yeast, because these microorganisms are quite beneficial for microbiological and microscopic studies. Fig. 1 shows the dependence of COD on the microbial number for the dispersion of yeast.

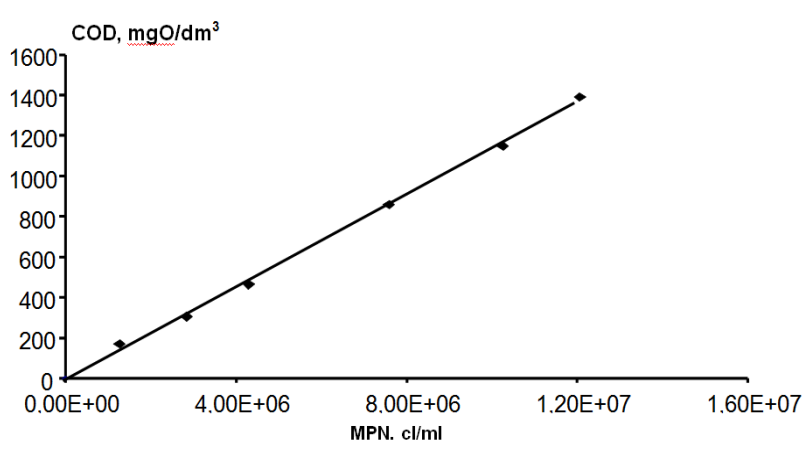

Fig. 1. The dependence of COD on MPN of dispersions with yeast concentrations of $0.8-20 \mathrm{~g} / \mathrm{dm}^{3}$

It is obvious that with increasing content of microorganisms in the system, the value of COD increases in direct proportion to the concentration of microorganisms. This makes it possible to estimate the value of $\mathrm{COD}$, which is determined by the concentration of microorganisms of a certain nature in the presence of organic substances in water. It was found that a sufficiently high concentration of microorganisms $\left(10^{5}-\right.$ $10^{6}$ cells $\left./ \mathrm{cm}^{3}\right)$ in water causes a relatively small value $\left(10-100 \mathrm{mg} / \mathrm{cm}^{3}\right)$ of chemical oxygen demand. It should be noted that the use of COD to determine the degree of contamination of water by microorganisms is impractical, because even with biological pollution, which is several orders of magnitude higher than when water is no longer suitable for consumption, $\mathrm{COD}$ is only 150 $180 \mathrm{mgO} / \mathrm{dm}^{3}$. The dependence shown in Fig. 1, can be used to calculate the concentration of organic substances in the presence of a significant number of microorganisms 
per unit volume of water or in the rapid method of determining MPN, as the standard method is long (more than 2 days), because COD is directly proportional to the number of microorganisms in water. Therefore, we can assume that the presence of microorganisms in real waters with a microbial count $\left(50-10,000\right.$ cells $\left./ \mathrm{cm}^{3}\right)$ does not significantly affect the accuracy of COD analysis and the contribution of biological contamination to total value of COD in real water research systems can be ignored.

The efficiency of ultrasonic treatment of contaminated water largely depends on the presence of impurities, concentration and nature of various microorganisms [11]. We studied the change of the concentration and destruction of yeast and rot microorganisms, as well as water-soluble organic substances in the aqueous dispersion of yeast.

Determining the microbial number in water usually takes several days, which is difficult, and in some cases does not allow to estimate the concentration of microorganisms in the water, because during this time there is growth, reproduction, or death of microorganisms in the test water. That is why we have proposed an express method for estimating the concentration of yeast cells in water by the turbidity of the aqueous dispersion. However, this method is limited by the fact that in the presence of inorganic materials particles in water, the data obtained may be inflated.

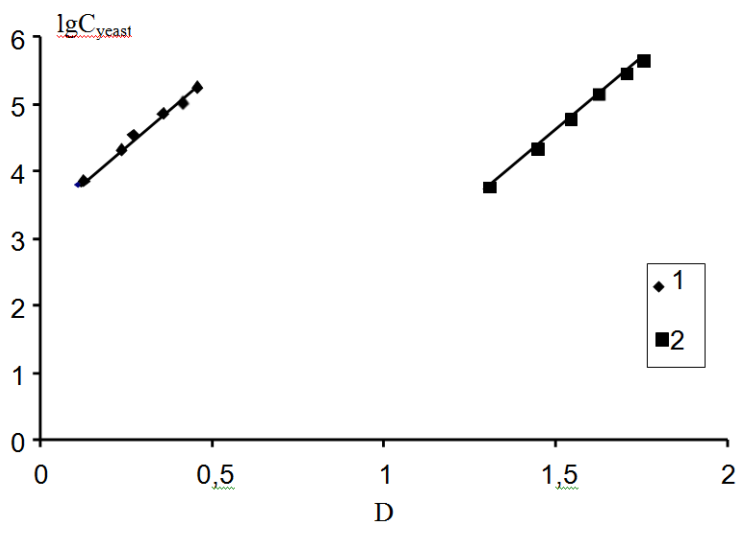

Fig. 2. Semi-logarithmic dependence of yeast concentration on the optical density of yeast dispersions with concentrations of $0.2(1)$ and $1.6(2) \mathrm{g} / \mathrm{dm}^{3}$

Decreasing the initial concentration of yeast cells leads to an increase in the rate of change of optical density, and in both cases there is a linear dependence of the logarithm of the optical density on the storage time of the dispersion. The correlation coefficients in all cases exceeded 0.96 . The decrease of optical density in time may be associated with the death of microorganisms during storage and their stabilization in aqueous dispersion due to organic substances present in the initial dispersion of yeast, or released during the destruction of
We found that in the wave range of $364-434 \mathrm{~nm}$, the dependence of the optical density on the concentration of microorganisms at all wavelengths is described by Eq. (1) (Fig. 2):

$$
D=1.59 \cdot \lg C_{\text {yeast }}
$$

The obtained data show that the change in the optical density of the dispersion can be used to estimate the change in the magnitude of microbiological contamination and, accordingly, to study the influence of various factors on this process.

The studies of the change in the dispersion optical density over time have shown that during the dispersion of dry yeast in water, in an inert atmosphere, the optical density of the dispersion increases for $2 \mathrm{~h}$ and remains almost constant with stirring for $6 \mathrm{~h}$. This indicates that the equilibrium state in the system occurs after $2 \mathrm{~h}$ of dispersion. It should be noted that when you stop mixing, the part of the dispersed cells precipitates within 10 $15 \mathrm{~min}$, forming a dense precipitate at a sufficiently large initial concentration of yeast. During storage of the yeast dispersion in stationary conditions (without mixing), the deposition of some microorganisms is observed, and the deposition rate depends on the initial concentration of cells in the dispersion (Fig. 3).

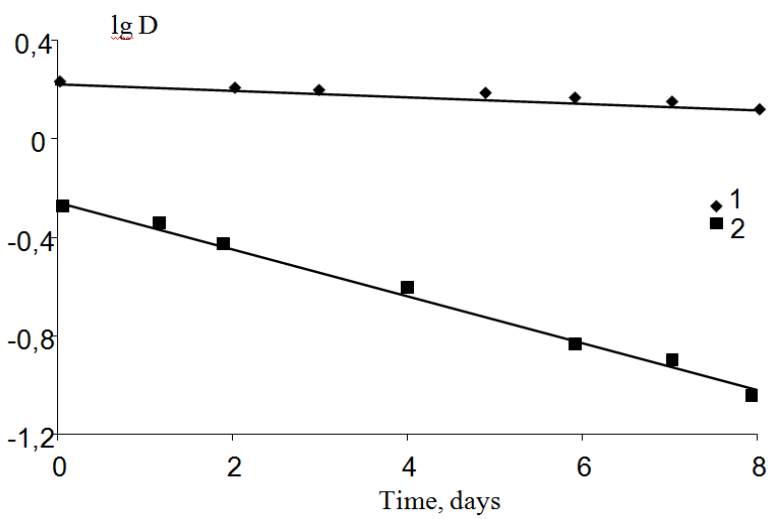

Fig. 3. Dependence of the optical density of the yeast cells dispersion on time in semi-logarithmic coordinates at an initial yeast concentration of $0.8(1)$ and $0.4 \mathrm{~g} / \mathrm{dm}^{3}(2)$

microorganisms $[7,11,12]$. On the other hand, the increase of the rate of microorganisms destruction in the volume with a decrease in their initial concentration (Fig. 3) may be due to redispersion of cells from the sediment formed during the cessation of mixing at high initial yeast concentrations, and in which the process of yeast destruction flows at a much slower rate than in the upper layers of the tank. The decrease of the cells number, both in the surface layer and in volume, is obviously associated with the autolysis of yeast cells - the destruction of cell 
components under the influence of its own enzymes and dissolved oxygen as a result of biochemical processes occurring in the cell and do not stop after the cell death. During autolysis, the structure of cells is destroyed and the activity of hydrolytic enzymes increases, which contribute to their destruction with the formation of proteins, hydrocarbons, fats, low molecular weight destruction products, which diffuse through the cell walls into the solution. During the hydrolytic destruction of intracellular components, nucleic acids, products of lipid peroxidation after autolysis and hydrolysis, biologically active substances and vitamins get into the aqueous solution [13, 14]. Based on the data of Fig. 4, it can be concluded that amine is mainly released during yeast autolysis and oxidative decarboxylation of the amino acids isolated by them, because $\mathrm{pH}$ of the dispersion increases with the number of destroyed yeast cells. It should be noted that $\mathrm{pH}$ of the dispersion increases from 5.3 to 6.6-6.8, and then remains almost constant (Fig. 4).

The fact that the processes of cell destruction occur with the participation of oxygen, indicates the changes in their content in the system under aerobic and anaerobic conditions. To study and analyze the effect of oxygen on the development of microorganisms in the cylinder sediment, experiments were performed under anaerobic conditions.

The study of $\mathrm{pH}$ and dispersion optical density (Table) shows that under anaerobic conditions the

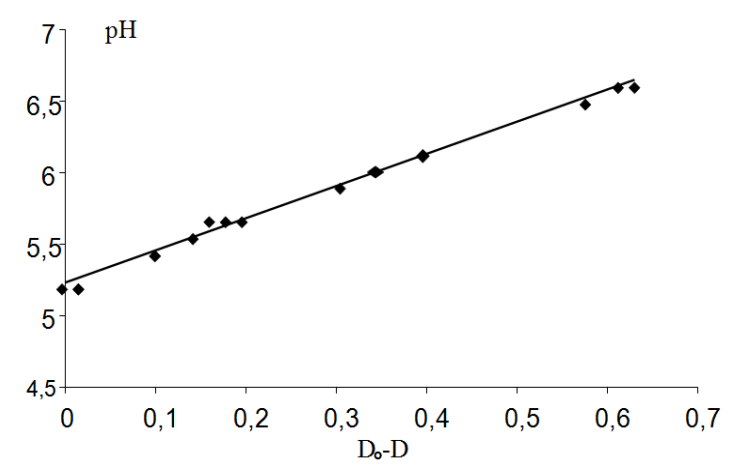

Fig. 4. The effect of the number of destroyed yeast cells in the volume on $\mathrm{pH}$ of the medium at an initial yeast concentration of $0.1-0.8 \mathrm{~g} / \mathrm{dm}^{3}$ destruction of yeast cells has a much slower rate and, in contrast to dispersions stored under aerobic conditions, their $\mathrm{pH}$ decreases, indicating a different mechanism of formation and composition of water-soluble organic substances. Therefore, under aerobic conditions, the access of oxygen to the sediment at the bottom of the cylinders occurs at a sufficient rate of the yeast cells oxidative destruction. This indicates that the rate of oxygen diffusion from the surface to the bottom of the cylinder is much higher than that of yeast cells and their products of destruction under experimental conditions. That is, the concentration of oxygen at the bottom of cylinders provides the close to the maximum oxidation rate of the organic medium.

During the storage of yeast dispersions in the air, the concentration of yeast cells in both the surface layer and the volume of water decreases according to the $1^{\text {st }}$ order equation. This is evidenced by the linear dependence of the function in the coordinates $\lg C_{\text {yeast }}=$ $=f(t)$ with the same angle of inclination at different initial concentrations of yeast cells in the surface layer (Fig. 5). It should be expected that the destruction of microorganisms leads to an increase in the concentration of organic matter in the solution, which stabilizes the cells of microorganisms in the dispersion. This is confirmed by the data of Fig. 3 regarding the change in the optical density of the dispersion at different initial concentrations of yeast.

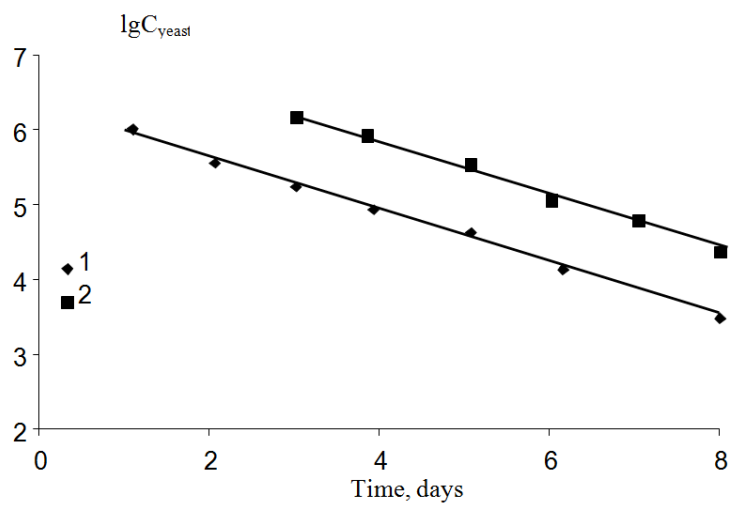

Fig. 5. Semi-logarithmic dependence of the content of live yeast cells in the surface layer of water on time at an initial yeast concentration of $0.8(1)$ and $0.4 \mathrm{~g} / \mathrm{dm}^{3}(2)$

Table

The changes of the optical density and $\mathrm{pH}$ of water dispersions of yeast under aerobic and anaerobic conditions at an initial concentration of microorganisms of $0.4 \mathrm{~g} / \mathrm{dm}^{3}$

\begin{tabular}{|c|c|c|c|c|}
\hline Time, day & $D$ (aerobic) & $\mathrm{pH}$ (aerobic) & $D$ (anaerobic) & $\mathrm{pH}($ anaerobic) \\
\hline 0 & 0.34 & 5.1 & 0.34 & 5.4 \\
\hline 8 & 0.06 & 6 & 0.25 & 3.2 \\
\hline 9 & 0.06 & 5.8 & 0.28 & 3.9 \\
\hline
\end{tabular}


Measurement of the COD value in the surface layer of water shows that the value grows slowly and reaches a maximum within 6-10 days. As shown above, the value of COD is associated with the presence of living yeast cells $\left(C_{\text {yeast }}\right)$. In addition, the COD value is due to the concentration of water-soluble organic products of the destruction of microorganisms $\left(C_{\text {org.sub }}\right.$. $)$. Therefore, the value of the total chemical oxygen demand of yeast dispersions in water will be proportional to the concentration of yeast and organic compounds and can be calculated by the ratio:

$$
\mathrm{COD}=a_{1} \cdot C_{\text {yeast }}+a_{2} \cdot C_{\text {org. sub }}
$$

where $a_{1}$ and $a_{2}$ are the coefficients of proportionality; $C_{\text {yeast }}$ and $C_{\text {org. sub. }}$ are concentrations of yeast living cells and water-soluble organic substances in the surface layer of water.

Since the concentration of water-soluble organic matter is almost proportional to the decrease in the number of cells in the volume of the solution, it is possible to take:

$$
C_{\text {org. sub. }}=a_{3} \cdot\left(D_{0}-D\right)
$$

where $a_{3}$ is the coefficient of proportionality, $D_{0}$ and $D$ are the initial and current optical density of the microorganisms dispersion.

Transforming Eq. (2) and taking into account Eq. (3), we obtain a linear relationship:

$$
\left.\mathrm{COD} / C_{\text {yeast }}=a_{1}+a_{2} \cdot a_{3} \cdot\left(D_{0}-D\right)\right) / C_{\text {yeast }}
$$

As can be seen from Fig. 6, the obtained data are well described by Eq. (4).

The correlation coefficient of the line is equal to 0.989 , and the values of $a_{1}$ and $a_{2} a_{3}$ are equal to $(6.4 \pm 0.4) \cdot 10^{-3} \mathrm{mg} / \mathrm{g}$ and $280 \pm 20 \mathrm{mg} / \mathrm{dm}^{3}$, respectively. Given the obtained data, the values of COD in the aqueous dispersion of yeast should be related to the concentration of living cells in the system by the ratio:

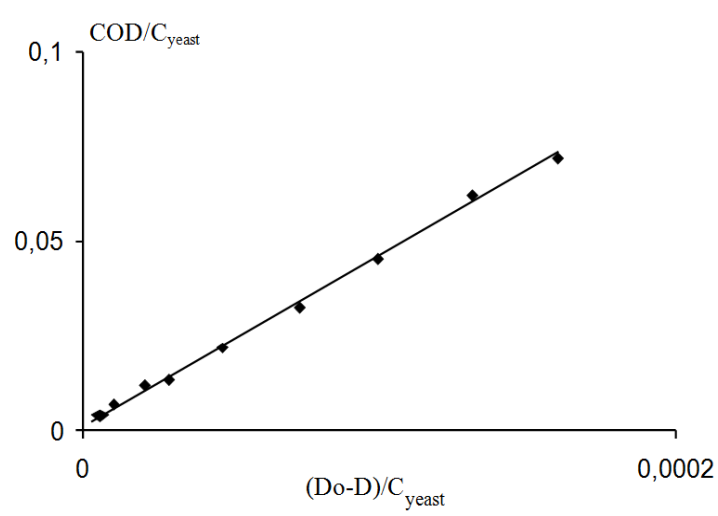

Fig. 6. The dependence of the ratio of COD to the concentration of living yeast cells in the surface layer of water in time on the ratio of the optical density of the dispersion of yeast cells in volume to the concentration of yeast cells in the coordinates of equation (4) at initial yeast concentrations of $0.1-0.8 \mathrm{~g} / \mathrm{dm}^{3}$

$$
\mathrm{COD}=\left((6.4 \pm 0.4) \cdot 10^{-3} \cdot C_{\text {yeast }}+(280 \pm 20) \cdot\left(D_{0}-D\right)\right.
$$

Taking into account the calculated constants and kinetics of live microorganisms destruction in the surface layer of water (Fig. 5), the equation shows that in the initial period of 1-2 days the COD value is determined by the number of living microorganisms, and after 3-4 days the main contribution is made by the concentration of water-soluble products of their destruction, which are formed in the dispersion volume and diffuse into the surface layer of water. The optical density of the dispersed system was measured for yeast. For rot microorganisms this parameter can be ignored, because during the experiment their concentration is almost equal to the error of the experiment. It should be also noted that the contribution of water-soluble organic substances in the value of $\mathrm{COD}$ is much greater than the cells of microorganisms in the surface layer of water under equilibrium conditions.

Increasing the amount of organic matter in the surface layer for 2-4 days leads to the emergence of a nutrient medium for rot microorganisms, which begin to actively multiply for 3-4 days after receiving yeast dispersions. In a week their number remains constant within 2 months. According to Fig. 7 it can be concluded that between the number of cells of rot microorganisms after 1-2 months from the beginning of the experiment and the value of COD there is a linear relationship in logarithmic coordinates.

It should be noted that the concentration of rot microorganisms up to 3-4 days of the experiment is low enough to significantly affect the value of water COD. Under anaerobic conditions, the concentration of such microorganisms is much lower and fluctuates within the error of the experiment; the presence of oxygen in the system promotes their development.

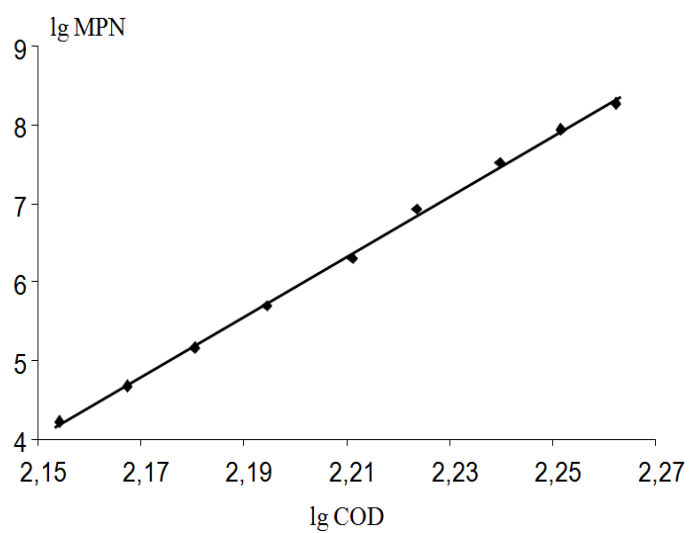

Fig. 7. The dependence of the concentration of rot microorganisms in the surface layer of water on the water COD in logarithmic coordinates for the initial concentrations of yeast cells in the range of $0.2-0.8 \mathrm{~g} / \mathrm{dm}^{3}$ 
Establishment of the Regularities of the Concentrations Change of Microorganisms and Water-Soluble... 413

\section{Conclusions}

The regularities of changes in the concentration of microorganisms and water-soluble organic compounds in polluted water under the conditions of cavitation treatment and the influence of the amount of biological water pollution on the value of chemical oxygen demand were investigated. It was shown that under aerobic conditions the destruction of yeast cells could be described by the firstorder equation. The destruction of cells leads to the release into the water environment of water-soluble organic substances that stabilize the dispersion of microorganisms. The decrease of optical density in time may be due with the destruction of microorganisms during storage and their stabilization in the aqueous dispersion due to organic substances present in the initial dispersion of the yeast, or released during the destruction of microorganisms.

The dependence of the COD value on the microbial number of contaminated water and the change in time of the concentration of microorganisms and water-soluble organic substances in contaminated water treated with ultrasound under aerobic and anaerobic conditions were studied. It is shown that the COD value of water in the surface layer is determined by the concentration of living yeast cells in the initial period and water-soluble products of their decomposition after 3-4 days from the preparation of yeast dispersions. The rot microorganisms begin to actively multiply in 3-4 days after the start of the experiment and the environment for their reproduction is water-soluble organic matter formed as a result of autolysis and oxidative destruction of yeast cells. It is established that the value of COD of the system containing microorganisms is directly proportional to the number of microorganisms, but in the actual water systems, the contribution of biological pollution in total value of COD can be ignored.

\section{References}

[1] Adhena A., Hayelom D., Abduljeleel A.: Environ. Sustain., 2019, 2, 199. https://doi.org/10.1007/s42398-019-00056-2
[2] Shevchuk L., Aftanaziv I., Falyk T.: Chem. Chem. Technol., 2017, 11, 475. https://doi.org/10.23939/chcht11.04.475

[3] Malollaria L., Pingulia R., Buzob V., Lajoic S.: J. Environ. Prot. Ecol., 2019, 20, 432.

[4] Aderibigbe D., Giwa A., Bello I.: The Imam J. Appl. Sci., 2017, 2, 27. https://doi.org/10.4103/ijas.ijas_11_17

[5] Myrto-Panagiota Z.: Circular Economy and Sustainability, 2021. https://link.springer.com/article/10.1007/s43615-021-00025-0

[6] Ruqiong Q.: IOP Conf. Ser.: Earth Environ. Sci., 2018, 170. https://doi.org/10.1088/1755-1315/170/3/032041

[7] Budgen J., Le-Clech P.: H2Open J., 2020, 3, 32. https://doi.org/10.2166/h2oj.2020.023

[8] Shevchuk L., Falyk T., Nykulyshyn I., Melnyk S.: East-Europ. J. Enterp. Technol., 2017, 3, 56. https://doi.org/10.15587/17294061.2017.101708

[9] Zacharof M.-P.: Circ. Econ. Sust., 2021. https://doi.org/10.1007/s43615-021-00025-0

[10] Bakarea K., Shabanguab M.: S. Afr. J. Chem. Eng., 2017, 24, 128. https://doi.org/10.1016/j.sajce.2017.08.001

[11] Starchevskyy V., Pohrebennyk V., Bernatska N., Typilo I.:

Water Supply and Wastewater Disposal, Monograph. Politechnika Lubelska, Lublin 2018.

[12] Starchevskyy V., Bernatska N., Typilo I. et al.: Chem. Chem. Technol., 2018, 12, 462. https://doi.org/10.23939/chcht12.04.462

[13] Swati H., Lodgeb J., Trabold T.: Renew. Sustain. Energy Rev., 2018, 81, 510. https://doi.org/10.1016/j.rser.2017.07.012

[14] Starchevskyy V., Bernatska N., Typilo I., Khomyshyn I Chem. Chem. Technol., 2017, 11, 358.

https://doi.org/10.23939/chcht11.03.358

Received: November 29, 2020 / Revised: December 12, 2020 / Accepted: January 23, 2021

\section{ВСТАНОВЛЕННЯ ЗАКОНОМІРНОСТЕЙ ЗМІНИ КОНЦЕНТРАЦІЙ МІКРООРГАНІЗМІВ ТА ВОДОРОЗЧИННИХ СПОЛУК У ЗАБРУДНЕНІЙ ВОДІ ПІСЛЯ ОБРОБЛЕННЯ УЛЬТРАЗВУКОМ}

Анотація. Досліджено закономірності зміни концентрачії мікроорганізмів та водорозчинних органічних сполук у забрудненій воді в умовах кавітаційного оброблення та вплив величини біологічного забруднення води на величину показника хімічного спожсивання кисню.

Ключові слова: ультразвук, Saccharomyces cerevisiae, руйнування мікроорганізмів, клітини дріжджів, кінетика реакиіï. 